\title{
Performing Identity: The Politics of Culture in Contemporary Puerto Rico
}

Aaron Gamaliel Ramos

\section{(2) OpenEdition}

\section{Journals}

Electronic version

URL: http://journals.openedition.org/plc/249

DOI: $10.4000 /$ plc. 249

ISSN: $2117-5209$

\section{Publisher}

L'Harmattan

Printed version

Date of publication: 14 January 2004

Number of pages: $63-80$

ISBN: 2-7475-7061-4

ISSN: $1279-8657$

\section{Electronic reference}

Aaron Gamaliel Ramos, «Performing Identity: The Politics of Culture in Contemporary Puerto Rico », Pouvoirs dans la Caraïbe [Online], 14 | 2004, Online since 18 January 2011, connection on 30 April 2019 URL : http://journals.openedition.org/plc/249; DOI : 10.4000/plc.249 


\title{
PERFORMING IdenTITY: \\ The Politics of Culture in Contemporary Puerto Rico
}

\author{
by Aarón Gamaliel Ramos \\ Professor of Social Sciences \\ University of Puerto Rico \\ Rio Piedras Campus
}

Culture has been a major theme of political debate in Puerto Rican politics. Nearly everywhere in the political arenas of twentieth century Puerto Rican we find references to culture and identity in the political discourse of both the metropolitan power and domestic political actors. Underlying the three major ideologies - independence, autonomy and full annexation to the US - are conceptions about the culture of the territory. Contrasting narratives involving language, ethnic and racial characteristics and the interpretation of history reveal the underlying tensions of historical and current colonialism. There have been two sources for cultural imaginings: the conception of the territory elaborated by metropolitan actors, manifested in official reports and texts related to the process of governing the territory; and the idealizations and practices related to the dynamics of resistance and accommodation of domestic political actors.

This article is primarily an exploration of some of the ways in which culture has been interpreted and performed in contemporary Puerto Rican political arena. In Puerto Rico, the politics of identity has been historically manifested in different ways, from intellectual debates over the cultural portrayal of the territory, to the utilization of governmental resources for the implementation of cultural policies, to the performance of identity in the political arena as political parties and movements strive to enrich their political projects with proposals on issues related to collective identification and loyalty to the State. In this article, my main concern is the elaboration of identities by social and 
political movements from the early years of the Commonwealth ${ }^{1}$ arrangement established in the aftermath of World War II, to its expression in contemporary Puerto Rican politics.

\section{TWO NATIONALISMS}

The early years of United States domination of Puerto Rico fostered the emergence of two antagonistic views of the Island in its relationship to the metropolis. While the Island had been a Spanish colony for almost 400 years, the colonial arrangement created in the aftermath of the Spanish American $\mathrm{War}^{2}$ shaped a political context characterized by the opposition of some sectors to the new colonial venture and political adaptation of others. To a large extent, the struggle between an alliance of autonomistas and independentistas during the first three decades of the twentieth century and an emerging pro-annexationist ideology highlighted contrasting ideals of collective identification. The political ideologies that clashed during the first half of the Twentieth century involved two visions of Puerto Rican in its relationship with the new metropolitan power: an ethnic-based conception of the nation nourished by the cultural traits and the habits of social life of the territory; and an ideological standpoint that considered the metropolis to be the nation of which the territory was a component ${ }^{3}$. These were key factors informing political party organization and ideological affinities during the early decades of United States colonialism.

\footnotetext{
${ }^{1}$ With the establishment of the Commonwealth in 1952 the US ended five decades of direct colonial rule, allowing for the creation of an autonomous entity under congressional jurisdiction. The Spanish name of this arrangement is Estado Libre Asociado, or Free Associated State. See, Antonio Fernos Isern, Estado Libre Asociado: antecedentes, creación y desarrollo hasta la époica presente, San Juan, Editorial Universitaria, 1974.

${ }^{2}$ In the Treaty of Paris of 1898 Spain yielded its sovereignty over Cuba and ceded Guam, the Philippines and Puerto Rico to the United States. See, Documents on Constitutional History of Puerto Rico, Washington, Office of Puerto Rico, nd.

${ }^{3}$ Here I am using the distinction made by Ernest Gellner, who argues the existence of an "ethnic" nationalism and a "civic-territorial" nationalism. See, Ernest Gellner, Nations and Nationalism, London, Blackwell Publishers, 1983.
} 
Cultural nationalism was the most salient expression of opposition to US colonial rule during the early decades of the twentieth century, until a radical nationalist posture emerged during the 1930s. Early Puerto Rican nationalism was historically related to the various expressions of nationalism developed elsewhere in the colonies of Spain in the region during the nineteenth century. The nationalist ideas in Puerto Rico had in common with other nationalist manifestations in the Hispanic Caribbean its reference to the land, language, folklore, and ethnic solidarity as primary sources of identity ${ }^{4}$. However, it developed distinctive features in the US colonial setting. Cultural ancestry was a central ingredient of nationalist descriptions of Puerto Rican identity, which called the attention to the differences between the Protestant and Anglo Saxon metropolis and the Catholic and Hispanic nation. While nationalist ideas in the Spanish colonies generally showed disdain for the Spanish colonial legacy ${ }^{5}$, Puerto Rican nationalist beliefs celebrated the Island's ties to European civilization through its history with Spain, "the mother country", in its effort to go up against the rhetoric of civilization that was part of United States colonialism.

The political discourse on the Puerto Rican nation alternated with another form of nationalism principally espoused by those sectors concerned with the annexation of Puerto Rico to the United States. This nationalist version minimized the ethnic component of social solidarity and, in its stead, emphasized the belonging to the powerful metropolitan State, stressing the worth of democratic culture in transforming the backward Spanish cultural legacy. Its discourse made intensive use of the political iconography and patriotic practices of the metropolitan state, such as celebrating the founders of the metropolitan nation, displaying the flag of the United States, and attempting reconciliation between

\footnotetext{
${ }^{4}$ More or less the variety Edouard Glissant refers to as "root identities". See his, Poetics of Relation, Ann Arbor, The University of Michigan Press, 1997, p. 143.

5 As historian James W. Cortada notes, "Spanish Americans generally held Spain in contempt after independence, often referring to the mother country as a land of corruption and decadence, reeking religious fanaticism and intolerance". In James W. Cortada (ed.), Spain in the Nineteenth Century: Essays on Spanish Diplomacy, 17891898, Westport, Connecticut and London, Greenwood Press, 1994, p. 60.
} 
domestic cultural traits and membership in the metropolitan nation through the autonomy afforded by federalism ${ }^{6}$.

To a large extent the political conflict during the early decades of US rule revolved around the issue of language. To begin with, the metropolis made English the language of government and the school system, generating resistance from intellectuals and the landholding classes, both of which were adversely affected by US colonial policies? In addition, the ability to speak and understand the English language was a key factor in gaining access to government posts ${ }^{8}$. While race was both a factor in the historical trajectory of Puerto Rico through the experience of slavery and an ingredient of US colonial discourse on the territories, local groups disregarded race as an identity mark, as one tendency attempted to represent a nation where ethnic solidarity overshadowed racial differentiation, and the other attempted to improve the odds of political assimilation by representing a territory with a white majority. Conversely, language was a crucial element of discord between both views and remained so throughout the course of the twentieth century as it became a factor informing local identity and the outcome of the relationship with the United States.

\section{PUERTO RICAN HOMELAND ${ }^{9}$}

In 1952 the United States granted Puerto Rico an autonomous status, as part of a political restructuring of the Caribbean region set off through the post war decolonization process. After World War II Great Britain oriented its colonies in the direction of independence, France opted for assimilation of its old colonies, and the Netherlands and the

\footnotetext{
${ }^{6}$ Edgardo Meléndez, Puerto Rico Statehood Movement, New York, Westport and London, Greenwood Press, 1988.

${ }^{7}$ See, Angel G. Quintero Rivera, Conflictos de classe y politica en Puerto Rico, Rio Piedras, Ediciones Huracán, 1976.

${ }^{8}$ Samuel Silva-Gotay, Protestantismjo y politica en Puerto Rico, 1898-1930, San Juan, Editorial de la Universidad de Puerto Rico, 1997.

${ }^{9}$ See, "Patrie et Citoyenneté : la construction politique de l'identité portoricaine", in Fred Constant and Justin Daniel (eds.), Politique et Développement dans les Caraïbes, Paris, L'Harmattan, 1999.
} 
Performing Identity:

The Politics of Culture in Contemporary Puerto Rico

United States retained colonial control of their territories while providing them with self-government.

In the search for legitimation, the governing Popular Democratic Party (PDP) intensely worked on the spheres of juridical and cultural interpretation. On the one alleging that Puerto Rico had in fact reached an accord with the metropolis to install an autonomous state "in free association with the United States"10. The other was the project for constructing a Puerto Rican patria (or, homeland) from the ruins of the old colonial setting. In the words of one of the leading intellectuals of that area, under the hegemony of the PDP, Puerto Rico had commenced its journey from being a multitude to being a people ${ }^{11}$. These two ideas were sustained through the strong alliance between the Populares and the nationalist intelligentsia, and through the cultural and educational policies of the Commonwealth government.

This period is important as an interruption of the debates that characterized the first half of the century and the ideological reconciliation of two conflicting issues: culture and citizenship. The political arena created under the Commonwealth shifted the terms of the cultural debate. With the conclusion of the Americanization effort that had characterized US cultural policies all the way through the first four decades of the century, and the doctrine of Pan Americanism, whereby Puerto Rico would become a cultural bridge between bridge between the United States and Latin America, on account of its historical and linguistic ties to the region. In such a context the ethnic characteristics of the territory gained symbolic value.

${ }^{10}$ For the proponents of the Free Associated States of Puerto Rico, United States petition to the UN to remove the island from the list of the non self-governing territories revealed the intention of an agreement. However, in fact, the territory never ceased to be held in control of the US Congress as a non-incorporated territory. José Trías Monge, Puerto Rico: The Trials of the Oldest Colony in the World, New Haven and London, Yale University Press, 1997.

${ }^{11}$ Vincente Géigel Polanco, El despertar de un pueblo, San Juan, Biblioteca de Autores Puertorriqueños, 1942. 
It is particularly relevant to note that the idea of a homeland in postwar Puerto Rican politics was based on an instrumental conception of citizenship. Without a significant exception the discourse on citizenship assumed a silence of metropolitan culture or political participation in its midst. In turn, it was understood as allowing for the unrestricted travel to the United States, and as a vehicle for enjoying the benefits of the welfare state.

The conflict between the two nationalisms in the Puerto Rican political arena over the first half of the twentieth century was dissipated in the post-World War II context by the elaboration of a vision of "the Puerto Rican people" that made a clear distinction between the cultural and the political sphere. The Puerto Rican intelligentsia actively participated in the crafting of the ideology of the Commonwealth. Through governmental agencies, the University of Puerto Rico and other institutions, there was an organized effort for academic interpretation of the juridical dimension of the new arrangement, historical revisionism, and the sociological and anthropological conceptions of culture ${ }^{12}$.

The old quest for building a separate nationality was replaced by an essentialist conception of Puerto Rico in which root identity and allegiance to the metropolitan State were blended. The intellectual proposal for the building of a homeland disconnected the two conflicting spheres of identification ingrained in the ideologies of the two nationalisms. On the one hand, the homeland referred to the realm of values and sentiments that defined the Puerto Rican personality; on the other, political democracy and citizenship corresponded to the State. Commonwealth advocates celebrated the social solidarity provided by culture, but underlined the loyalty to citizenship and democratic values ingrained in the US system ${ }^{13}$. In his inaugural address of January 1953,

\footnotetext{
${ }^{12}$ In the 1940 s a Columbia University team led by anthropologist Julian Steward made a study of various subcultures in the Island, questioning the nationalist vision of a national culture. Julian Steward, The People of Puerto Rico, Urbana, Illinois, The University of Illinois Press, 1956.

${ }^{13}$ Antonio Fernós Isern, "Razones políticas, socials, económicas, culturales y morales por las cuales Puerto Rico debe continuar siendo un Estado Libre Asociado".
} 
Performing Identity:

The Politics of Culture in Contemporary Puerto Rico

Governor Luis Muñoz Marín summarized the concept in the following way: "Puerto Ricans are today a Hispanic-American people composed of good citizens of the United States"14.

Intellectuals during the early Commonwealth period worked on an image of Puerto Rico as a nation with a strong Hispanic proportion to which it was added elements of indigenous and African culture ${ }^{15}$. The understanding of culture was centered in the rural traditions embodied by the spirit of the jibaro, or landless peasant. It was in many ways a constructed with rural agrarian elements, excluding such crucial elements as the growing urban communities and the traditions ingrained in through the history of slavery in the Island. The Commonwealth wrote Fernández Méndez in 1959, is a special situation that allows for the reconciliation of the Hispanic traits of the population with the democratic rationality of the United States political system ${ }^{16}$.

A particularly relevant development was the establishment of the Institute of Puerto Rican Culture (IPC) in charge of the promotion of cultural development around the island ${ }^{17}$. The ICP had a crucial role in the invention of identity during the early years of the Commonwealth, portraying Puerto Ricans as a cultural community built from the crossfertilization of Hispanic, Indian and African elements. From its creation in 1956, the IPC unfolded its program promoting and supporting cultural institutions around the island, in support of the notion that Puerto Rico was a people and, such, required a separate collection of images as a

Conference in the Ateneo de Ponce, November 28, 1958. See also, Francisco Ayala, "The transformation of the Spanish Heritage", in Puerto Rico: A Study in Democratic Development, The Annals of The American Academy of Political and Social Science, Vol. 285, January, 1953.

${ }^{14}$ Cited by Henry Wells, The Modernization of Puerto Rico : A Political Study of Changing Values and Institutions, Cambridge, Harvard University Press, 1969, p. 240.

${ }^{15}$ Eugenio Fernández Méndez, Puerto Rico: Filiación y sentido de una isla: cuatro ensayos en busca de una comunidad auténtica, San Juan, Departamento de Instrucción Públkoica, 1955, pp. 44-45.

${ }^{16}$ Puerto Rico: filiación y sentido de una isla, p. 44.

17 See, Arlene M. Dávila, Sponsored Identities: Cultural Politics in Puerto Rico, Philadelphia, Temple University Press, 1997. 
cultural entity in the American world ${ }^{18}$. Through autonomy Puerto Rico was believed to be a haven for internal cultural development without the destructive aspects of continental politics ${ }^{19}$.

Throughout its initial years, the ideology on culture of the Commonwealth neutralized both the nationalist and pro-annexationist discourses on culture ${ }^{20}$. It is not difficult to understand how this view of a Puerto Rican homeland in the midst of the US political system could dissipate the historical struggle over identity. While the appearance of a strong cultural discourse placated the nationalist sector, its lack of political claims was palatable to an annexationist movement concerned solely with the "preservation of the American flag" in the island ${ }^{21}$.

\section{PERformances ON IDENTITY}

The autonomist project, with its representations, narratives and practices, can best be understood as a calculated reformulation of the guiding principles of historical colonialism in the particular scenario of the postwar, when the interests of the metropolis and those of important sector of Puerto Rican society coincided. However, this was not an enduring period. The rural and traditional setting that gave birth to the ideals of a Puerto Rican homeland was drastically transformed through industrialism, urbanization, massive migration and other processes that

\footnotetext{
${ }^{18}$ Carlos Gil, "Subjetividad nacional y dispositivo cultural de Estado: la legislación cultural puertorriquenia", in Carmen I. Rafucci, Silvia Alvarez Curbelo and Fernando Picó (eds.), Senado de Puerto Rico, 1917-1992: Ensayos de historia institucional, San Juan, Senado de Puerto Rico, 1992.

${ }^{19}$ Puerto Rico, wrote Spanish intellectual Francisco Ayala, "has taken from American politics the sanest principles and practices, without yet spreading in the Island certain pernicious aspects of continental politics. On the other hand, the liberal spirit of that system has permitted the development of a growing political autonomy of the Island". Francisco Ayala, op. cit., p. 106.

${ }^{20}$ Arcadio Díaz, La memoria rota: ensayos sobre cultura y politica, San Juan, Ediciones Huracán, 1993.

${ }^{21}$ I have examined this period of the history of the annexationist movement in "La revista 'El Estado' en la historia del anexionismo puertorriqueno, 1945-1960". Revista de Historia 1:2, julio-diciembre 1985, pp. 215-221. See also Robert Anderson, Party Politics in Puerto Rico, Stanford, Stanford University Press, 1965.
} 
Performing Identity:

The Politics of Culture in Contemporary Puerto Rico

ended the populist period inaugurated under the PDP and molded the modern era in Puerto Rican politics. Also, the main beliefs of the Commonwealth showed signs of decay during the late 1960s when the Populares lost their electoral hegemony to the New Progressive Party (NPP), initiating a period of political party sharing the reigns of government.

\section{Ethnic Performances}

The breakdown of the cultural policies under the Commonwealth gave way to widely divergent discourses and practices on identity. To begin with, the symbolic value of autonomy was damaged by the lost of administrative control of the government and its cultural institutions. Moreover, because of the widespread experience of migration, the land and folklore became vulnerable elements as a referent for identity ${ }^{22}$. Nevertheless, the deep-rooted cultural representations in the ideal of the homeland continued to mold the political discourse despite the fading of the circumstances that nourished its birth. Thus, the two dominant ideas on Puerto Rican identity in the political arena during the last three decades, owe their intellectual and political leanings to cultural beliefs of the early post war.

In modern Puerto Rican political life the capacity of the local government to contribute effectively to the construction of social reality through long-term representations has been impaired by its powerlessness and limited resources. Both in its contents and in its audience, the construction and performance of identities in current political life of Puerto Rico reveal a double resonance: on the one side, a political discourse for an internal audience; and, on the other, a set of discourses and practices to a metropolitan audience. It is thus less concerned with establishing a universal standpoint on identity, as in the past, and more eager to "perform" a representation.

\footnotetext{
22 Justin Daniel, "Dynamique migratoire et recomposition identitaire: le cas portoricain", in Fred Reno (dir.), Identité et politique. De la Caraïbe et de l'Europe multiculturelles, Paris, Economica, 1995, pp. 95-118.
} 
During the period from 1976 to 1992, two antagonistic visions on culture were unveiled. On the one hand, the proposal for a Creole statehood $^{23}$ that was introduced by the NPP in the political arena of the 1970s made a drastic departure in annexationist cultural views. Earlier annexationist ideas on this subject emphasized universal cultural values, reducing ethnicity to a primitive sentiment that would in time yield its way to world-scale pluralism ${ }^{24}$. The new proposal not only addressed the prevailing cultural nationalist mood in the Island, but also was attentive of the public debate in the United States on civil rights, and receptiveness of the Carter administration over issues of race and ethnicity.

By representing Puerto Rico as an ethnic group within the United Sates, the NPP was able to align itself with the discourse on cultural nationalism while maintaining its commitment to the ideal of equality within the US political system. To a significant degree, the modern annexationist project retained intellectual ties with Commonwealth beliefs on culture and citizenship, as it laid out its double claim to an allegiance to a local community, through its commitment to "the preservation of our identity as a people", and the economic value of US citizenship.

"We Puerto Ricans are committed to the preservation of our identity as a people, and we are also committed to the preservation of our [United States] citizenship. It is our duty to insist in obtaining political equality. The Irish people conquered it, Italians conquered it, the Jewish conquered it, and the Blacks are conquering it. Puerto Ricans should also conquer it" ${ }^{25}$.

\footnotetext{
${ }^{23}$ Aarón Gamaliel Ramos, « El anexionismo como proyecto histórico: del estado criollo a la anexión clásica", in Ivonne Acosta (ed.), Controversias históricas, Cuadernos del Ateneo, 4:2, San Juan, Librería Editorial Ateneo, 1995.

${ }^{24}$ In 1964, Luis Ferré cautioned that: "The modern world is abandoning cultural nationalisms. The old concept of cultural differentiation is dying. In its place, we should enrich ourselves with the diversity of cultures". Aarón Gamaliel Ramos, Las ideas anexionistas en Puerto Rico bajo la dominación noretamericana, San Juan, Ediciones Huracán, 1987, p. 46.

${ }^{25}$ Las ideas anexionistas, p. 47.
} 
While avowedly critical of Commonwealth as a colonial status, and celebrating full-fledged annexation, NPP intellectuals and strategists did little in the way of transforming the terms of the debate ${ }^{26}$. In the conception of the Puerto Rican identity advanced by the NPP, the preservation of language as an identity mark of Puerto Ricans was crucial. Although conservative republicans in the metropolis had made significant inroads in their aspiration to make English the official language of the United States, the NPP conceived language to be "a legitimate patrimony reserved to the States and to the people under the Tenth Amendment" dealing with the Rights of States under the Constitution $^{27}$. In stressing the belonging to a cultural community, albeit in a "minority" role, the NPP sustained the value of cultural solidarity in its political project. Still, a cultural offensive on autonomy with a new discourse on identity was initiated when the PDP regained control of the government in 1984.

\section{Performances on Language}

Language has been the most persistent theme of the politics of culture in Puerto Rico. It was a major gravitational point of political discourse during the first colonial period as I have pointed out. Nonetheless, the establishment of Spanish as the language of public education in 1949, allowed the Puerto Rican government to work on an autonomous educational policy, relocating language from the spotlight of political conflict into a more discreet issue of political debate.

External forces have spurred the resurgence of the debate on language in the contemporary political setting. The debate on language in

\footnotetext{
${ }^{26}$ A length study outlining the strategies and possibilities of statehood asserted the clearly distinguishable traits of Puerto Rico since "the Island represents a unique cultural and social phenomenon within the American experience". Grupo de Investigadores Puertorriquenos, Breakthrough from Colonialism: An Interdisciplinary Study of Statehood, 2 volumes, San Juan, Editorial de la Universidad de Puerto Rico, 1984.

${ }^{27}$ This Amendment states; "The powers not delegated to the United States by the Constitution, nor prohibited by it to the States, are reserved to the States respectively, or to the people". Breakthrough from Colonialism, p. 1478.
} 
the United Sates has had an impact on Puerto Rican politics as both major governing ideologies in the Island have seen it as a reference to their relationship to the United States ${ }^{28}$. Without the emphasis that has been placed on language in recent metropolitan debate it is improbable that the early post war consensus on this issue would have been damaged. While Congress has historically called for attention to the importance of English as part of the functioning of a state in the US system it has been the conservative move to establish English as the official language of the United States that has prompted the recent language debate. Both the administration of Rafael Hernández Colón (1985-1991) and that of Pedro Rosselló (1992-2001) played the language game with intensity. The former was most active in the cultural debate, using the state apparatus to forge a new representation of the people of Puerto Rico with a markedly European accent. The celebration of 500 years of "Discovery of America" by Colombus, in 1992 provided the stage for the elaboration of a new thesis on cultural identification in which Puerto Rico was proclaimed to be as a Hispanic society "homogeneous in its culture and language".

There was a significant departure from traditional Commonwealth cultural ideology, as the forging of a new discourse on identity attempted to weigh up the share of cultural ingredients ${ }^{29}$. Contrary to the populist construction of the founder of the Commonwealth, this new version was seated in an elitist celebration of Spain and Spanish colonization in the

\footnotetext{
${ }^{28}$ Many members in the House Committee of the Interior and Insular Affairs, which is responsible for the territories, believe that any real path towards full incorporation would entail a serious consideration of this issue. Moreover, the two conservative moments to make, English Only and English First, had voiced concerns on accepting a Spanish speaking state. Pedro Juan Rúa, La encruijada del idioma: ensayo en tornoal inglés official, la defense del español criollo yh Ika descolonización puertorriqueña, San Juan, Instituto de Cultura Puertorriqueña, 1992. See also, Nancy Morris, Puerto Rico: Culture, Politics and Identity, Westport and London, Praeger Publishers, 1995, pp. 60-61.

${ }^{29}$ In responding to questions on Puerto Rican culture made to him in Spain, the governor went as far as to say that African contribution to Puerto Rican culture was mere "rhetorical ascription".
} 
Americas $^{30}$. While in the identity discourse of Commonwealth supporters during its early years Puerto Ricans was a cultural blend of Spaniards, the Taino indigenous population, and Africans, the conception advanced by autonomists during the early 1980s highlighted European ancestry and the Spanish language, and relegating the contribution of the popular culture, particularly its African component. The nostalgic imagining of a Puerto Rican people tied to the Spanish mother country was influenced by two major events. Internally, there was the new economic strategy attempt by the government of Puerto Rico to foster the investment of Spanish capital, in finances and communications, to confront economic crisis in the territory. The discourse on a Hispanic identity served as a backdrop for the investment of Spanish capital in the island, allowing Puerto Rico to enter "a new century of economic relations based on competitiveness, self-reliance and economic exchanges with Europe". Externally, it was a reaction to the rise of a discourse on cultural homogeneity in the United States and the movement for establishing English as an official language of the metropolis.

The Spanish language became e renewed ingredient of internal debate and a salient item in the search for political autonomy, as US policymakers perceived the emphasis on a Spanish identity as an impediment for full-fledged integration of the territory into the $\mathrm{US}^{31}$. Language was centerpiece of the debate, as the PDP controlled legislature enacted the Language Law of 1991, declaring Spanish as the sole language of the Puerto Rican government, thus breaking with a 1902 law that made both English and Spanish official languages.

\footnotetext{
${ }^{30}$ During the signing of the bill the governor declared "our mother tongue to be the most precious sign of our identity". The enthusiasm with Spain and Spanish colonization is best represented in Rafael Castro Pereda, España en América; cinco siglos en perspective, San Juan, n.e, 1985.

${ }^{31}$ On this subject see, Idsa Alegría Ortega, "Culture, Politics and Self-Determination in Puerto Rico", in Aarón Gamaliel Ramos and Angel Israel Rivera (eds.), Islands at the Crossroads: Politics in the Non-Independent Caribbean, Kingston, Boulder and London, Ian Randle and Lynne Rienner Publishers, 2000, pp. 28-44.
} 
"Our identity comes not from our citizenship, but from being part of the people of Puerto Rico, a human collectivity with common blood, land, history, will, culture and destiny",32.

The definition of a Puerto Rican identity based on the saliency of Hispanic traits was an ephemeral occurrence. Even as language was placed as an issue of identity, the language debate did not address the issue of the diversity of the language experience of Puerto Ricans in the metropolis and the territory ${ }^{33}$. Despite its reception in Spain, the debate on language this time around took place in a society in which English, while not being a language spoken by a majority of the population ${ }^{34}$, was recognized by the population as an important language ${ }^{35}$. In breaking from the historical emphasis on local culture and folklore in the construction of identity to the underscoring language as an identity mark, autonomist theorists broke away with the postwar consensus on this issue $^{36}$ initiated a period of symbolic struggles around identity and patriotism $^{37}$.

${ }_{32}^{32}$ Puerto Rico: Culture, Politics and Identity, p. 60.

33 "La vida inclemente", in Arcadio Díaz Quiñones, La memoria rota: ensayos sobre cultura y politica, San Juan, Ediciones Huracán, 1993.

${ }^{34}$ Census reports during the Commonwealth era reveal a gradual percentage increase in the population able to speak English, from 37.7 in 1960, to 42.7 in 1970, to 45.6 in 1980, to 50.5 in 1990. In Roamé Torres González, Idioma, bilingüismo y nacionalidad: la presencia del ingles en Puerto Rico, San Juan, Editorial de la Universidad de Puerto Rico, 2002, Table 2, p. 152.

${ }^{35}$ Frances Negrón Muntaner, «English Only jamás, but Spanish Only cuidado: language and Nationalism in contemporary Puerto Rico ", in Frances Negrón Muntaner and Ramón Frosfoguel (eds.), Puerto Rican Jam: Essays on Culture and Politics, Minneapolis, University of Minnesota Press, 1997.

${ }^{36}$ See Roamé Torres González, Idioma, bilinguismo y nacionalidad, op.cit., pp. 212214. See also, Rafael Castro Pereda, Idioma, historian y nación, San Juan, Editorial Talleres, 1993.

${ }^{37}$ Luis Ferre, the founder of the NPP objected to the exclusion of the English language from its appropriate place as a "symbol of our loyal association with the United States". Culture, Politics and Identity, p. 59. 
Performing Identity:

The Politics of Culture in Contemporary Puerto Rico

\section{Patriotic Performances}

Symbols have played a major role in the politics of cultural identification in Puerto Rico. The nationalist ideologies that have traversed the history of the island have imprinted major legacies in the utilization of political language. Patriotism, as it is used in Puerto Rico, may refer to two distinct types of adherences: to the nation or to the metropolitan State.

The basic form of the discourse on the Puerto Rican nation makes reference to social solidarity (or more specifically, "communal" solidarity since the nation is conceived of as a people sharing common traits). One is loyal to the history of the nation and committed to the preservation of its traits. In turn, State patriotism in a colonial setting, such as the one we are scrutinizing, must resort to the most salient signs of the presence of the metropolitan power in the territory. Language and the flag are probably the most salient symbols of political identification.

Although it would be wrong to downplay the ethnic factor in the struggles over identity, what is significant in the game of identities in Puerto Rican politics during the last decades is the perception of the limits of ethnicity as a source of internal mobilization and political performance. During its eight years at the helm of the territorial government an NPP administration under Pedro Rosselló made dramatic departures from the established vision of Creole statehood taking the bolder path of conceiving Puerto Ricans as full-fledged Americans, through citizenship and the habits of social life.

At the present juncture the politics of identification has been the politics of identity has shifted another notch, from cultural representations to the sphere of political loyalties. Thus beyond language (which continues to be a major source of identity construction), a major igniting element of political debate in the current Puerto Rican political arena has been US naval control of the island of Vieques ${ }^{38}$. Here again, changes in the policies and discourse of the metropolis have stirred local

\footnotetext{
${ }^{38}$ An easternmost island that served as naval target for almost 6 years before a recent decision made by the President of the US to discontinue naval practices there.
} 
passions. One strikingly similar aspect of both tendencies is their resort to flag displaying and flag waiving ${ }^{39}$.

I have suggested in the title of this essay that in modern Puerto Rico the construction of identities by political parties and movements is not seated in a long term transformation corresponding to well defined ideological goals, but rather to junctural constructions for both local and external audiences, nourished by shifting circumstances. There is still the lingering question as to the extent to which these ideas actually "represent" the visions of the agents to which they are addressed. While cultural and historical continuities are undeniable factors influencing social life, actual experience is hardly encapsulated into essential categories built by the State and its agents.

\footnotetext{
${ }^{39}$ An analysis of "the flag war" has been made by Juan Manuel Carrión, "La Guerra de las banderas: lealtades en conflicto", Paper presented at the $27^{\text {th }}$ Annual Conference, Caribbean Studies Association, The Bahamas, May 27-June 1, 2002.
} 


\section{AbSTRACT}

This essay explores the breakdown of the concepts of "fatherland" and "citizenship" in the political construction of identity in Puerto Rico. It focuses on the impact of political transformations in the post Cold War political scenario upon the political debate on ethnicity and identity. The article is divided in two parts: one that considers the construction of identity during the early stages of Commonwealth development and another that examines the limits of cultural differentiation. The main argument is that Commonwealth development was tied to the process of mobilization for modernization whereas increasing metropolitan intervention in the social sector, the concomitant weakening of the Commonwealth State have impacted upon the construction of political identity. The paper explores also the forces

\section{RESUME}

Cet essai explore la place des concepts de "patrie » et de "citoyenneté " dans la construction politique de l'identité à Porto Rico. Il se concentre sur l'influence des transformations politiques sur le débat relatif à l'ethnicité et à l'identité dans le scénario politique de l'après Guerre froide. L'article est divisé en deux parties: la première envisage la construction de l'identité durant les premières étapes du développement de l'Etat libre associé (ELA); la seconde examine les limites de la différenciation culturelle. L'argument principal est que le développement de l'ELA a été associé au processus de mobilisation pour la modernisation tandis que l'intervention métropolitaine croissante dans le secteur social et l'affaiblissement concomitant de l'ELA ont influencé la construction de l'identité politique. L'article explore 
configuring regionalization in the political discourse of the State and political parties. aussi les forces configurant la régionalisation dans le discours politique de l'Etat et des partis politiques. 